\title{
Um rumor de anjos no mundo desencantado: outros desafios à teologia
}

FRANCISCO GENCIANO JR ${ }^{1}$

Dartindo das análises de Peter Berger sobre a redescoberta do sobrenatural L na sociedade moderna e de suas sugestões para a teologia quanto aos métodos a serem assumidos no processo de identificação de sinais de transcendência na sociedade, assim como das considerações de Max Weber quanto ao denominado desencantamento do mundo, duplamente introduzido, pela ciência e pela própria religião, procuram-se identificar quais desafios estão se apresentando para a reflexão e ação teológicas nessa interface entre realidades sociais desmagificadas e novas religiosidades magificadas com perspectivas muito mais imediatas e centradas na vida presente do que na expectativa de um porvir suplantador da realidade material.

Palavras-chave: sobrenatural; transcendência; desencantamento; magia; teologia.

\section{A rumor of angels in the disenchanted world: other challenges to theology}

tarting from Peter Berger analysis about the discovery of the supernatural $\checkmark$ in modern society and its suggestions for theology about the methods to be

1 Graduado em Teologia e mestrando em Ciências da Religião pela Universidade Metodista de São Paulo. E-mail: francisco.genciano@hotmail.com 
assumed in the process of identification of transcendence signal in society as well as the Max Weber's considerations about the so-called disenchantment of world, doubly introduced by science and religion itself, looking up to identify what challenges are presenting themselves for reflection and theological action at interface between disenchanted social realities and new enchanted religiosity, with much more immediate prospects and focused on this life than in anticipation of a future supplanter of material reality.

Keywords: supernatural; transcendence; disenchantment; magic; theology.

\section{Introdução}

Para a presente reflexão, tomamos como base o livro Um rumor de anjos: a sociedade moderna e a redescoberta do sobrenatural, de Peter Berger, originalmente escrito em 1969, traduzido para a língua portuguesa de 1997 (segunda edição revista). Na pesquisa realizada em seus manuscritos fica óbvia a necessidade de considerar as influências do tempo e do espaço em seus conteúdos. Os textos compilados no livro indicam que Berger (1997) escreveu, majoritariamente, em um contexto ocidental, primordialmente protestante, norte-americano e europeu, e para interessados em religião. Entretanto, o autor não deixou de introduzir, no capítulo intitulado Da secularidade às religiões mundiais, as peculiaridades do "Terceiro Mundo" no quesito "religião":

Se fosse perguntado sobre a experiência mais importante que conduz de um livro ao outro [Um rumor de anjos, 1969 e $O$ imperativo herético, 1979], eu diria que foi o Terceiro Mundo. Na década de 1960 eu estava preocupado com o problema da secularidade e Um rumor de anjos foi uma tentativa de superar a secularidade a partir de dentro. O Terceiro Mundo ensinou-me quão etnocêntrica era essa tentativa: hoje a secularização é um fenômeno de âmbito mundial, é verdade, mas ela está muito mais arraigada na América do Norte e na Europa do que em qualquer outra parte. Uma perspectiva mais global inevitavelmente proporciona uma visão mais equilibrada do fenômeno. Ao invés, o Terceiro Mundo impressiona com a enorme força social da religião (BERGER, 1997, p. 174). 
No prefácio de Um rumor de anjos, Berger (1997, p. 16) declara que o livro "não se dirige especialmente a sociólogos[...] [mas] a qualquer um que se preocupa com questões religiosas e que mostra boa vontade em pensar sobre elas sistematicamente". Na frase final do livro, Berger (1997, p. 228) esclarece uma vez mais sua intenção: "Minha preocupação aqui tem sido com alguns métodos possíveis de ir ao encalço desta questão em nossos dias".

A questão a ser perseguida é aquela sobre os sinais de transcendência na contemporaneidade, e Berger (1997) apresenta uma proposta aos teólogos sobre os métodos a serem assumidos nessa busca.

Independentemente da ressalva apresentada quanto ao contexto espaço-temporal, entendemos que estão presentes conceitos relevantes para reflexão dentro de nossa própria época e lugar.

Como parceiro para o diálogo convidamos Max Weber (2009), pela intermediação de Antônio Pierucci (2013), para nos falar sobre o desencantamento do mundo, conceito que entendemos de grande importância para que se possa pensar a religião, seja qual for a abordagem: sociológica, antropológica, teológica etc.

\section{Sobre a "suposta" morte do sobrenatural}

O afastamento do sobrenatural do mundo moderno - e a consequente descentralização da religião como doadora de sentido - é ponto convergente entre os comentaristas contemporâneos da religião. O quanto isso se deu e dá pode ser controvertido no que se referem a mensurações, métodos e abordagens. Pois, "longe ser um tema superado e/ou irrelevante para o mundo moderno, o fator religioso volta a exercer - senão simplesmente sustenta - um papel decisivo na maioria dos grandes processos sociais da atualidade" (OLIVEIRA; OLIVEIRA, 2012, p. 25).

De qualquer modo, Berger (1997, p. 20) questiona desde a maneira como a evasão do sobrenatural foi recebida, "com ira profética, em profundo pesar, com alegre triunfo, ou simplesmente como fato incapaz de provocar qualquer emoção", até a produção científica sobre o tema, que, para ele, deixa a desejar por fixar os olhos apenas para dentro dos quadros eclesiásticos.

A questão da morte do sobrenatural tem de ser respondida antes, em sua dependência à chamada teoria da secularização da cultura moderna, na mente dos indivíduos do que nas instituições sociais, o que 
seria entendido como uma secularização da consciência, enfim. E isso tudo conduz à pergunta sobre a existência de forças genuinamente religiosas fora do tradicional quadro de referência cristão ou eclesiástico. $\mathrm{O}$ crescimento constatado pelos últimos censos, dentro e fora do Brasil, do seguimento denominado como dos "sem religião" apontam para o que pode ser a confirmação dessa intuição de Peter Berger.

Para todos os efeitos, Berger (1997, p. 30) admite a viabilidade empírica da afirmação (da morte do sobrenatural) e sugere que os sobrenaturalistas verão suas crenças atingidas por intensas pressões tanto sociais quanto psicológicas. E essa é a deixa para abordar o que ele chama de "profunda crise teológica".

O teólogo, assente Berger (1997), também é — para espanto de alguns, talvez - um ser humano, e, por isso, existe em um meio social. Seria, portanto, ingênuo supor que a morte do sobrenatural fosse experimentada do mesmo modo por todos os que a ela foram apresentados.

Continuarão a existir ambientes religiosos e teológicos nos quais a crise é, no máximo, vagamente sentida à distância, como uma ameaça externa. Em outros ambientes, ela está começando a ser sentida, mas está "ainda se desenrolando". Em outros ambientes, porém, está em plena erupção, como uma ameaça bem dentro, no fundo da estrutura de fé, prática e pensamento religiosos. E em alguns lugares é como se o crente ou teólogo estivessem em pé num cenário de ruínas em lenta combustão (BERGER, 1997, p. 31).

O protestantismo foi o segmento religioso que vivenciou mais intensamente essa crise. Compreensível, afinal, o pensamento protestante é aquele que sempre se abriu ao espírito da modernidade, e não só isso, desempenhou também papel significativo na própria gênese do mundo moderno. "Seja lá como for, pode-se perceber no pensamento protestante, por bem mais de um século, uma maior tendência de acomodação à moderna mundanidade" (BERGER, 1997, p. 32).

Berger (1997, p. 32) vai apresentando os movimentos havidos na teologia protestante, que, desde Schleiermacher (1799), com a publicação dos Pronunciamentos sobre Religião aos seus Eruditos Desdenhadores, cede ante seus antagonistas cognitivos, resultando em casos extremos de erosão dos conteúdos religiosos até "não sobrar nada mais que retórica". Passa por Karl 
Barth, identificado como aquele que "clamou por um retorno à fé clássica da Reforma, uma fé que, afirmava ele, era incondicionalmente baseada na revelação de Deus e não em qualquer razão ou experiência humanas" (BERGER, 1997, p. 33), chegando a Paul Tillich e Rudolf Bultmann.

Sem valer-se de eufemismos, Berger (1997, p. 35) conclui que "a autodestruição do trabalho teológico é empreendida com um entusiasmo que raia ao bizarro, culminando na redução ao absurdo da 'teologia da morte de Deus' e do 'ateísmo cristão"'.

As opções para a religião e para o pensamento teológico teriam, então, de ser feitas sob as condições de uma minoria cognitiva. Fundamentalmente, essa escolha oscila entre aferrar-se ao desvio cognitivo ou capitular. Isso tudo está no domínio das ideias, observa Berger (1997), acrescentando que é muito importante compreender que o resultado disso tudo tem implicações sociais práticas.

A opção de aferrar-se ao desvio cognitivo nada mais seria que uma tentativa de manter (ou possivelmente reconstruir) uma posição sobrenaturalista diante de um mundo cognitivamente antagônico. "O teólogo desta posição se prenderá ao seu trabalho, ao sobrenaturalismo e a tudo o mais, e o mundo (literalmente ou não) que se dane" (BERGER, 1997, p. 43).

Mas seria necessária uma "contracomunidade" de expressiva força para que o desvio cognitivo tivesse chance de se manter. Seria preciso uma espécie de gueto. Berger (1997) não vê a ocorrência de circunstância favorável para o estabelecimento de guetos, tanto por conta do pluralismo que conduz a sistemas de conhecimento abertos, que se comunicam e competem entre si, quanto pela tendência de governos democráticos modernos em não fomentar perseguições religiosas.

No polo oposto está o desafio da capitulação. Para Berger (1997) a tarefa intelectual básica assumida como resultado desta opção é a tradução, ou seja, as afirmações religiosas tradicionais são traduzidas em termos apropriados ao novo quadro de referência, que se supõe conformar-se à Weltanschauung ${ }^{2}$ da modernidade (BERGER, 1997, p. 46).

Independente das diferenças de método adotados nessas traduções, o resultado obtido é por demais semelhante em todos os casos, qual seja, "os elementos sobrenaturais das tradições religiosas são mais ou menos

2 Weltanschauung basicamente refere-se à orientação cognitiva fundamental (do indivíduo ou sociedade); cosmovisão, mundividência. 
completamente eliminados e a linguagem tradicional é transferida de referências do outro mundo para este mundo" (BERGER, 1997, p. 47).

Esse cristianismo secularizado faz esforços consideráveis para demonstrar que o rótulo religioso, alterado de acordo com o espírito da época, tem qualquer coisa especial a oferecer. O que ocorre, entretanto, é que, para a maioria,

\begin{abstract}
Símbolos cujo conteúdo foi esvaziado não convencem nem mesmo interessam. Em outras palavras, a rendição teológica à suposta morte do sobrenatural derrota-se a si mesma na exata proporção de seu sucesso. Em última análise, representa a autodestruição da teologia e das instituições na qual a tradição teológica está corporificada (BERGER, 1997, p. 48).
\end{abstract}

Berger (1997) aponta que no processo de pechinchar cognitivamente ocorre uma contaminação cognitiva mútua, prevalecendo, naturalmente, o mais forte. E se a tese da secularização estiver correta, por consequência o mundo moderno será o mais forte, nele, sabemos, o sobrenatural tornou-se - ou foi tornado - irrelevante.

Entretanto, Berger (1997, p. 52-53) afirma, existe

Evidência generalizada de que a secularização não é tão abarcadora assim, como muitos pensaram, de que o sobrenatural, banido da respeitabilidade cognitiva por autoridades intelectuais, pode sobreviver em recantos e fendas ocultas da cultura. Mas nesta matéria não estão tão ocultas assim. Continua a haver manifestações bastante maciças daquele sentido do misterioso que o racionalismo moderno chama de superstição[...] Sejam quais forem as razões, números consideráveis do espécime do "homem moderno" não perderam a propensão para o admirável, o misterioso, para todas aquelas possibilidades contra as quais legislam os cânones da racionalidade secularizada.

E a condição humana, permeada de sofrimento e com a morte à frente, reclama por interpretações que além de satisfação teorética deem sustentação interior para o enfrentamento da crise do sofrimento e da morte. Mencionando estar acompanhando Max Weber, Berger (1997) afirma que há uma necessidade mais social que psicológica de teodiceia. 
Originalmente a teodiceia referia-se às teorias que buscavam explicar (ou conciliar) um Deus todo-poderoso e o mal (físico e moral) existente no mundo, e Weber ampliou o termo para abarcar qualquer explicação teorética do sentido do sofrimento ou do mal.

\begin{abstract}
As teodiceias seculares falham, contudo, na interpretação e consequentemente na tentativa de tornar mais suportáveis os paroxismos do sofrimento humano. Falham notavelmente na interpretação da morte. O caso marxista é instrutivo. A teoria marxista da história fornece realmente uma espécie de teodiceia: todas as coisas serão restauradas na utopia pós-revolucionária[...] Mas a sabedoria do marxismo dificilmente proporcionará muito conforto a um indivíduo enfrentando uma operação de câncer (BERGER, 1997, p. 54-55)
\end{abstract}

Berger (1997) salienta que as observações por ele registradas não têm a pretensão de ser um argumento a favor da verdade da religião. Por ser a verdade talvez incômoda e sem um sentido último para a esperança humana, aquele estoicismo que poderia abraçar tal categoria de verdade é raro. As pessoas, em sua maioria, parecem querer (precisar?) de um maior conforto e, até agora, foram as teodiceias religiosas que o forneceram. Por isso, seria legítimo pensar que, "no mínimo, bolsões de religião sobrenaturalista provavelmente sobreviverão dentro da grande sociedade" (BERGER, 1997, p. 55).

É um prognóstico bastante razoável de que num mundo "livre de surpresas" a tendência geral da secularização continuará. Uma impressionante redescoberta do sobrenatural, nas dimensões de um fenômeno de massa, não está nos livros. Ao mesmo tempo, áreas significativas de sobrenaturalismo continuarão a se encravar na cultura secularizada [...] As grandes organizações religiosas continuarão provavelmente sua infrutífera busca de um meio-termo entre o tradicionalismo e o ajornamento, tendo pelas pontas o sectarismo e a dissolução secularizante sempre importunando. Este não é um quadro dramático, mas é mais adequado que as visões proféticas quer do fim da religião, quer de uma época próxima de deuses ressuscitados (BERGER, 1997, p. 55-56). 
Berger (1997) até aqui delineou as facetas da situação na qual se encontra contemporaneamente o ato de pensar a religião. Apesar de admitir não ser possível pensar a religião ou qualquer coisa em independência e abstração da situação tempo-espaço, afirma que sua preocupação reside mais no nível da verdade que da epocalidade. Cabendo à perspectiva sociológica avançar um pouco além da simples diagnose atual.

\section{A sociologia e a relativização de si}

No Ocidente moderno, o homem aparenta ter perdido a capacidade de repetição, e mesmo de compreensão da condição estática anteriormente comum à prática de muitos cultos religiosos.

Essa perspectiva sociológica, segundo Berger (1997), se constitui no novo riacho de fogo (referência ao velho trocadilho de Marx para com o nome de Feuerbach) através do qual o teólogo tem que passar. Observa que, mais precisamente, o desafio contemporâneo à teologia está na sociologia do conhecimento.

A crença profunda no conflito entre teologia e ciências físicas, "que Max Weber denominou com aptidão de desencantamento do mundo" (BERGER, 1997, p. 60), provoca um intenso sentido de abandono, que, por outro lado, não é impedimento para apaixonadas afirmações teológicas. Pascal e Kierkegaard seriam exemplos disto.

Pulando de um lado ao outro do argumento, Berger (1997) afirma que a história e a psicologia foram os predecessores da sociologia no estabelecimento da crise atravessada pela teologia. A história levou até os mais sagrados elementos da tradição religiosa a serem vistos como produções humanas, e a psicologia, após Freud, sugeriu que a religião é uma projeção de necessidades e desejos humanos. Assim, história e psicologia seriam as responsáveis por arremessar a teologia em um redemoinho de relativizações, cabendo à sociologia a intensificação do desafio posto à teologia.

Assim é, pois, que a pesquisa sociológica, em sua dimensão mais óbvia, dá ao teólogo um sentido de seu próprio estado minoritário na sociedade contemporânea, demonstrando, para isso, que a proposição basilar da sociologia do conhecimento é a aquela de plausibilidade:

[...] o sentido daquilo que as pessoas realmente acham digno de fé, das ideias sobre a realidade depende do suporte social que estas ideias recebem. Dito mais simplesmente, 
nós conseguimos nossas noções sobre o mundo originalmente de outros seres humanos, e estas noções continuam sendo plausíveis, para nós em grandíssima parte, porque os outros continuam a afirma-las. (BERGER, 1997, p. 66).

Obviamente, pode-se ir contra o consenso social, mas há que se ver em uma refrega com fortes pressões, inclusive as psicológicas, que atuam dentro da própria consciência. Além disso, "parece haver práticas organizadas destinadas a silenciar dúvidas e prevenir lapsos de convicção" (BERGER, 1997, p. 66). São as chamadas legitimações, próprias ao convencimento de que aquilo que se diz não é apenas sensato, mas é, sobretudo, a única coisa certa e salutar. Deste modo, as concepções de mundo podem ser analisadas nos termos de suas próprias estruturas de plausibilidade, "porque só quando o indivíduo permanece nesta estrutura é que a concepção do mundo em questão permanecerá plausível a ele" (BERGER, 1997, p. 67).

Compreendendo que todas as afirmações humanas submetem-se a processos sócio-históricos cientificamente inteligíveis, Berger (1997) levanta a questão acerca da veracidade ou falsidade de tais afirmações:

[...] pode-se admitir que há no mundo moderno um certo (sic) tipo de consciência que tem dificuldade com o sobrenatural[...] Poderíamos concordar, digamos, com o fato de a consciência contemporânea ser incapaz de conceber anjos ou demônios. Ainda ficamos com a questão de saber se, talvez, anjos e demônios não continuam a existir, apesar desta incapacidade de nossos contemporâneos em concebê-los. Um traço (talvez literalmente) redentor da perspectiva sociológica é que a análise relativizadora, ao ser levada até suas últimas consequências, redobra-se sobre si mesma. Os relativizadores são relativizados, os desencantadores são desencantados - realmente, a própria relativização é de alguma forma liquidada. O que se segue não é, como alguns dos primeiros sociólogos do conhecimento temiam, uma total paralisia do pensamento. Antes, é uma nova liberdade e flexibilidade em fazer perguntas sobre a verdade (BERGER, 1997, p. 76).

O empenho de Berger (1997) é mostrar que as mundividências ancoram-se em certezas subjetivas ao mesmo tempo em que são sus- 
tentadas por estruturas de plausibilidade. O indivíduo moderno, assim, "existe numa pluralidade de mundos migrando de um lado a outro entre estruturas de plausibilidade rivais e muitas vezes contraditórias" (BERGER, 1997, p. 78). A base da crise religiosa da plausibilidade estaria na extrema dificuldade de "estar cognitivamente entre nous na sociedade moderna, especialmente na área da religião" (BERGER, 1997, p. 79).

Passando, de novo, para o outro lado do argumento, Berger (1997) nos diz que, diferentemente de outras disciplinas, que nos livram do peso morto do passado, a sociologia nos livra do peso morto do presente. Assim o faz, pois, ao dar compreensão aos sujeitos da própria situação em termos sociológicos, os livra daquela fatalidade inexorável, propiciando um incremento da capacidade investigativa de toda e qualquer verdade que venha a ter sido descoberta na peculiaridade de toda época. Nessa inversão sociológica residiria então um método teológico viável em resposta ao desafio da sociologia.

Com Feuerbach, [a teologia] era uma conversa entre o homem e as próprias produções do homem. Dito de outra forma, em vez de um diálogo entre o homem e uma realidade sobre-humana, a religião tornou-se uma espécie de monólogo humano. Poder-se-ia bem dizer que o tratamento da religião, não só por Marx e Freud, mas por toda a análise histórico-psicossociológica dos fenômenos religiosos desde Feuerbach tem sido primariamente uma vasta elaboração da mesma concepção e do mesmo procedimento. Uma teoria sociológica da religião, particularmente se empreendida no marco da sociologia do conhecimento, leva à suas últimas consequências a teoria feuerbachiana de religião como projeção humana, isto é, um produtor cientificamente cognoscível da história humana (BERGER, 1997, p. 82).

Entretanto, uma inversão de perspectiva é possível, e ambas podem coexistir. Aquilo que é tido como projeção humana numa perspectiva pode irromper como reflexo de realidades divinas na outra. A lógica da primeira perspectiva não impede a possibilidade da segunda

A decisão teológica terá que ser que, "em, com e sob" a imensa roupagem das projeções humanas, há indicadores de uma realidade verdadeiramente "outra" que, no final, a imagina- 
ção religiosa do homem reflete. Estas considerações indicam também um possível ponto de partida para a teologia, dificilmente o único, mas um ponto de partida capaz de enfrentar o desafio delineado acima. Este é o ponto de partida da antropologia, usando o termo no sentido global, como se referindo ao empreendimento filosófico que se preocupa com a pergunta "O que é o homem?" Se as projeções religiosas do homem correspondem a uma realidade que é sobre-humana e sobrenatural, então parece lógico procurar vestígios desta realidade no próprio projetor (BERGER, 1997, p. 84).

\section{A teologia e o ponto de partida antropológico}

Uma vez que as proposições teológicas mui raramente abordam o divino de si mesmo ou em si mesmo, mas a partir de suas relações e significados para o ser humano, uma antropologia poderia ser deduzida teologicamente, mas não se vislumbravam "possibilidades indutivas da antropologia à teologia" (BERGER, 1997, p. 87). E a sugestão de Peter Berger (1997) é exatamente essa: "que o pensamento teológico retorne a um ponto de partida antropológico" (BERGER, 1997, p. 89). E sua disposição para tal sugestão "é motivada pela crença de que esta ancoragem na experiência humana fundamental possa oferecer alguma proteção contra os ventos constantemente mutáveis dos estados de espírito culturais" (BERGER, 1997, p. 89).

Sugere, adiante, que um ponto de partida antropológico para a teologia seria a busca por sinais de transcendência no âmbito mesmo da situação humana empiricamente dada. Acrescentando ainda que existem gestos humanos prototípicos que poderiam constituir tais sinais de transcendência.

Por sinais de transcendência, Berger (1997) quer fazer significar os "fenômenos que se encontram no domínio da nossa realidade 'natural', mas que parecem apontar para além desta realidade". E por gestos humanos prototípicos quer indicar "certos atos ou experiências repetidos que aparecem como expressão de aspectos essenciais do ser humano, do animal humano como tal" (BERGER, 1997, p. 90). O autor ainda usa o termo transcendência com a noção já tratada de sobrenatural. São apresentados, então, cinco argumentos que buscam mostrar os gestos humanos prototípicos que desvelam sinais de transcendência: 
1. O argumento da ordem: A propensão para a ordem é tida por Berger (1997) como traço fundamental e de importância crucial na compreensão do empreendimento religioso do homem. Tal inclinação seria historicamente visível e verificável.
Através de quase toda a história, os homens acreditaram que a ordem criada da sociedade, de uma maneira ou de outra, cor- responde a uma ordem subjacente do universo, uma ordem divina que sustenta e justifica todas as tentativas humanas de pôr ordem (BERGER, 1997, p. 91).

Essa inclinação humana para estabelecer ordem estaria fundada numa fé ou confiança de que, em última análise, a realidade está "em ordem", está "tudo certo", está "como deve ser" (BERGER, 1997, p. 92). E seria neste sentido basilar que cada gesto de pôr em ordem seria um sinal de transcendência. Berger (1997) compara isto com o que Mircea Eliade chamou de "nomizações".

Dá como exemplo para seu argumento aquele da mãe que consola a criança que despertou assustada à noite por conta de um pesadelo. Assim fazendo, essa mãe "está sendo invocada como uma sumo-sacerdotisa da ordem protetora. É ela (e em muitos casos ela somente) que tem o poder de banir o caos e restaurar a forma benigna do mundo" (BERGER, 1997, p. 93). O exemplo, diz Berger (1997), pertence sim às experiências mais rotineiras da vida, que não dependem de qualquer preconceito religioso. Mas, questiona ele, mesmo nessa cena comum reside uma importante dimensão religiosa: "Estaria a mãe mentindo à criança?" (BERGER, 1997, p. 93).

A resposta seria não, apenas e tão

Somente se houver alguma verdade na interpretação religiosa da existência humana. Inversamente, se no "natural" é a única realidade que existe, a mãe estará mentindo a seu filhinho - mentindo por amor seguramente[...] — mas, em última análise, mentindo de todo jeito. Por quê? Porque a confiança reconquistada, transcendendo a dois indivíduos imediatamente presentes e sua situação, implica numa afirmação sobre a realidade como tal (BERGER, 1997, p. 93).

No cerne do processo de tornar-se plenamente humano, encontra-se uma experiência de confiança na ordem da realidade. Essa experiência seria 
uma ilusão e o indivíduo que o representa um mentiroso? Indaga retoricamente Peter Berger (1997) para, em sequência, apresentar a resposta:

Se a realidade for coextensiva à realidade "natural" que nossa razão empírica pode apreender, então a experiência é uma ilusão e o papel que a corporifica é uma mentira. Pois então é perfeitamente claro que tudo não está em ordem, não está certo. O mundo no qual se diz para a criança confiar é o mesmo mundo no qual ela finalmente morrerá. Se não houver outro mundo, então a verdade última sobre este mundo é que finalmente ele matará a criança bem como sua mãe (BERGER, 1997, p. 94-95).

A representação de um universo que está em ordem e é digno de confiança, apenas poderia ser justificada do lado de dentro de um quadro de referência religioso (sobrenatural). Dessa maneira, a propensão a pôr em ordem, inerente ao ser humano, encerraria uma ordem transcendente, e cada gesto ordenador um sinal desta transcendência. "A religião, pois não é só (do ponto de vista da razão empírica) uma projeção da ordem humana, mas (do ponto de vista do que poderíamos chamar de fé indutiva ${ }^{3}$ ) a justificação fundamentalmente verdadeira da ordem humana" (BERGER, 1997, p. 96).

2. $\mathrm{O}$ argumento do jogo: A alegria, como finalidade do jogo, tem um caráter de tornar-se eternidade. Ou seja, no jogo alegre é como se alguém estivesse saindo não só de uma cronologia para outra, mas do tempo para a eternidade. Os adultos, ao brincarem com legítima alegria, adquirem, naquele momento, uma vez mais, aquela ausência da morte tão presente na infância.

C.S. Lewis, num sermão proferido no começo da II Guerra Mundial, pôs isto de forma eloquente: "A vida humana sem-

3 Fé indutiva para Berger (1997, p. 96-97) significa qualquer processo de pensamento que começa com a experiência, sendo o inverso da dedução. Por "fé indutiva" ele se refere a um processo religioso de pensamento que começa com fatos da experiência humana, ou seja, vai da experiência humana para afirmações sobre Deus. A fé dedutiva, por outro lado, vai de afirmações sobre Deus para interpretações da experiência humana. 
pre foi vivida à beira de um precipício[...] Os homens[...] expõem teoremas matemáticos em cidades sitiadas, fazem argumentos metafísicos em celas de condenados, fazem piadas nos cadafalsos, discutem o último poema enquanto avançam para os paredões de Quebec e penteiam os cabelos nas Termópilas. Isto não é verve: é a nossa natureza"[...] o homem é profundamente homo ludens (BERGER, 1997, p. 99).

$\mathrm{O}$ argumento do jogo e o argumento da ordem compartilham de semelhante lógica. A experiência do jogo alegre não tem de ser procurada nas margens mística da existência. Ao contrário, é encontrada com facilidade no cotidiano, na realidade da vida ordinária. E, mesmo nesse âmbito, o da realidade experimentada, "constitui um sinal de transcendência, pois sua finalidade intrínseca aponta para além de si mesma e para além da 'natureza’ humana, para uma justificação ‘sobrenatural"' (BERGER, 1997, p. 101).

3. O argumento da esperança: Dentro da lógica da fé indutiva, reiterada por Berger (1997) ao longo de seu macro argumento, a esperança é apresentada como outro elemento construtivamente essencial à condição humana. [Ernst] "Bloch acentua que o ser do homem não pode ser adequadamente entendido a não ser em conexão com sua indomável propensão a esperar pelo futuro" (BERGER, 1997, p.102). Assim estaria a existência humana sempre norteada para o futuro, ou seja, o ser humano encontra realização em projetos. E a esperança é um aspecto fundamental desta futuridade do ser humano.

Sob o impacto da secularização, as ideologias da esperança intramundana distinguiram-se como teodiceias (sendo a marxista a mais importante ultimamente). Em todo caso, a esperança humana sempre se afirmou a si mesma mais intensamente diante de experiências que pareciam significar completa derrota, acima de tudo, diante da derrota final da morte. Assim as manifestações mais profundas da esperança devem ser encontradas em gestos de coragem feitos em desafio à morte (BERGER, 1997, p. 103).

O tipo de coragem ao qual Berger (1997) se refere é aquele que se liga às esperanças de criação, justiça ou compaixão humanas. Ou seja, li- 
gado a gestos de humanidade, afinal, lembra-nos, houve nazis corajosos. Enfim, é aquele "não!" à morte que está entranhado na própria essência do ser humano que se apresenta como mais um sinal de transcendência a reivindicar uma interpretação religiosa da situação humana.

Afinal, mesmo em um "mundo onde o homem está cercado de todos os lados pela morte, ele continua um ser que diz "não!" à morte — e através deste "não!" é levado à fé num outro mundo, cuja realidade valida sua esperança como algo diferente da ilusão" (BERGER, 1997, p. 107). A experiência cotidiana e natural da esperança apontaria também para uma realização sobrenatural.

4. o argumento da condenação: Mudando para um raciocínio distinto, mas mantendo a mesma lógica, Peter Berger $(1997,108)$ apresenta o argumento da condenação. Com isso, ele pretende fazer referência àquelas

Experiências nas quais nosso senso por aquilo que é humanamente permissível é tão fundamentalmente ultrajado que a única resposta adequada à ofensa, bem como ao ofensor, parece der uma maldição de dimensões sobrenaturais[...] A forma negativa do argumento faz com que a noção intrínseca do senso humano de justiça surja de maneira muito mais aguda como sinal de transcendência acima e para além das relatividades sócio-históricas.

É o argumento da condenação como senso humano de justiça, como sinal de transcendência. Não se trata apenas de uma condenação em seu caráter formal, jurídico e penal, mas condenação como danação, como punição transcendente. Danação no sentido plenamente religioso da palavra. Atos que são uma violação à consciência mais fundamental da constituição humana não são apenas maus, são monstruosos. Deste modo, o brado que se faz aos céus por justiça ecoa também no inferno. Assim, como os gestos anteriormente interpretados por Berger (1997) como antecipações redentivas, outros gestos podem ser antecipações do inferno.

A esperança e a danação são dois aspectos de uma mesma abarcadora justificação[...] O massacre dos inocentes[...] levanta a questão da justiça e poder de Deus. No entanto, 
sugere também a necessidade do inferno, não tanto como confirmação da justiça divina, mas antes como vindicação de nossa própria justiça (BERGER, 1997, p. 113).

5. $O$ argumento do humor: $O$ quinto e último argumento é o do humor, do cômico. O cômico é definido por Berger como sendo fundamentalmente a discrepância, incongruidade, incomensurabilidade. É a "discrepância fundamental da qual decorrem todas as outras discrepâncias cômicas [é] a discrepância entre o homem e o universo[...] O cômico reflete o aprisionamento do espírito humano no mundo" (ibid., p. 114).

O cômico, mais que uma reação subjetiva ou psicológica dessa realidade experimentada pelo ser humano, é uma dimensão objetiva dessa mesma realidade. Durante o intervalo cômico a tragédia humana, seja qual for, é suspensa, colocada entre parênteses. $\mathrm{O}$ riso pode fazer transcender os limites deste mundo, e o faz relativizando as aparentemente inabaláveis necessidades do mundo.

Ao rirmos do aprisionamento do espírito humano, o humor indica que este aprisionamento não é o final, mas será superado, e assim fornece ainda outro sinal de transcendência[...] Sustentaria, pois, que o humor, como a infância e o jogo, pode ser visto como uma justificação basicamente religiosa da alegria (BERGER, 1997, p. 115).

Berger (1997) afirma ter propositadamente omitido quaisquer discussões sobre as reivindicações da experiência religiosa direta (enquanto experiência do sobrenatural). Orientou e limitou seu argumento na discussão dos fenômenos encontrados na vida cotidiana de cada um. Retoma a questão da verdade dizendo que "assim, de maneira alguma é certo, mas perfeitamente possível, que hoje saibamos algumas coisas sobre o alcance da humanitas que nunca foram conhecidas antes" (BERGER, 1997, p. 120). Salienta ser possível também que povos antigos tivessem conhecimentos com os quais nunca sonhamos, e que se perderam nas brumas do tempo passado.

Aquilo que aceitamos como normalidade é, sobretudo, uma suspensão da dúvida, sem a qual a vida do dia-a-dia seria impossível. Impossível posto que assombrada e dominada por aquela constante invasão da "angús- 
tia fundamental causada pelo nosso conhecimento e medo da morte. Isto implica em que todas as sociedades humanas e suas instituições são, em sua raiz, uma barreira contra o terror nu" (BERGER, 1997, p. 120).

Esse lado noturno, essa angústia fundamental, ainda que exorcizado, mui raramente era negada. "Uma das consequências mais espantosas da secularização foi exatamente esta negação. A sociedade moderna expulsou a noite da consciência, o mais longe possível" (BERGER, 1997, p. 121). E não apenas eliminou as velhas questões metafísicas mais elementares sobre o sentido da condição humana, mas as liquidou teoreticamente, relegando-as ao absurdo.

O método teológico proposto por Berger pode contribuir para a "redescoberta do êxtase e da metafísica como dimensões cruciais da vida humana e pela mesma razão para a reconquista de riquezas perdidas da experiência e do pensamento" (BERGER, 1997, p. 122).

\section{Um rumor de anjos}

O tema de estudo deste artigo busca estudar as compreensões do autor BERGER (1997), destacado no início do texto, a respeito da redescoberta do sobrenatural na sociedade moderna, dando foco em suas sugestões para a teologia quanto aos métodos a serem assumidos no processo de identificação de sinais de transcendência na sociedade.

"Tudo está cheio de deuses", exclamou Tales de Mileto. O monoteísmo bíblico varreu os deuses na glorificação da terrível majestade do Único, mas a plenitude que dominou Tales continuou a viver por muito tempo nas figuras dos anjos[...] mensageiros (angeloi) deste Deus, sinalizando sua transcendência, bem como sua presença no mundo dos homens (BERGER, 1997, p. 224).

Foi somente com o começo da secularização que a plenitude divina começou a recuar, até que atingiu o ponto em que a esfera empírica se tornou abarcadora de tudo e perfeitamente fechada sobre si mesma[...] Há alguns anos atrás (sic), a um padre trabalhando numa favela de uma cidade da Europa, feZ-se a pergunta por que estava fazendo aquilo e respondeu: "Para que o rumor de Deus não desapareça completamente" (BERGER, 1997, p. 225). 
Berger (1997) declaradamente trata no livro da redescoberta do sobrenatural como possibilidade para o fazer teológico, e o faz com a proposição de métodos possíveis para se lançar na busca, ou ao encalço da questão nos dias atuais. Mas acentua ele que se deve manter uma saudável dose de indiferença em relação a possíveis prognósticos empíricos. "O curso histórico da pergunta sobre a transcendência não pode por si mesmo responder à pergunta" (BERGER, 1997, p. 228).

"Se os sinais de transcendência se tornaram rumores em nossa época, então nos podemos lançar na exploração destes boatos - e talvez segui-los até sua fonte" (BERGER, 1997, p. 226).

\section{O desencantamento do mundo}

O desencantamento do mundo - na plenitude de sua significação verificado por Max Weber cerca de um século atrás, ainda é um processo em aberto. Mesmo assim, a secularização é fruto de diagnósticos controversos, sendo até vista por alguns como um processo historicamente esgotado, tanto como teoria quanto como processo social (OLIVEIRA; OLIVEIRA, 2012).

A fim de pensarmos a proposta de Berger para a teologia, entendemos ser interessante identificar, a partir de Max Weber, o conceito de desencantamento do mundo no extenso processo de racionalização com a correspondente secularização. Para tal intento nos valeremos da definitiva contribuição do professor Antônio Flávio Pierucci (2013) que pontuou pormenorizadamente todos os passos do conceito.

Fica bem estabelecido na obra sobredita que o desencantamento do mundo se dá pela ciência e também pela religião. A ciência desencantando o mundo significa a perda de sentido, enquanto a religião desencantando o mundo implica em desmagificação. O conceito surge dezessete vezes na obra de Max Weber. Nove vezes para indicar desmagificação, quatro significando perda de sentido e, nas outras quatro vezes, carregam as duas significações (PIERUCCI, 2013, p. 58). Nota-se que o desencantamento do mundo pela religião (desmagificação) é abordado majoritariamente por Weber, e é exatamente esse o aspecto que talvez seja o menos compreendido.

O desencantamento propiciado pela ciência pode ser entendido como descentralização, ou descentramento. A intelectualização afasta a religião de seu outrora lugar central na doação de sentido para o universo e a vida, 
e a faz dividir, em maior ou menor grau, essa tarefa com a própria ciência, o Estado, a cultura e todos os outros sistemas de significados da sociedade moderna. "É isso que a ciência moderna faz em última análise [...] ela retira o sentido do mundo, agora transformando-o em 'mecanismo causal"' (BERGER, 1997, p. 159). E não apenas isso. O incremento da racionalidade axiológica, inerente mesmo ao próprio pensamento protestante, ameaça aquelas estruturas de plausibilidade mencionadas por Berger, dentro das quais o indivíduo precisa estar para ver sustentada sua mundividência.

A religião, agora, aparece como sem saída racional, desgarrada de sua velha orientação em direção a uma racionalização teórico-doutrinária sempre mais sofisticada e uma prática religiosa sempre mais sublimada racionalmente em termos éticos. Agora a religião afunda no irracional, "à medida que avança o desencantamento do mundo" (BERGER, 1997, p.79).

A racionalidade da magia - à qual podemos fazer aderir o conceito de Peter Berger para o sobrenatural - reside em seus fins práticos, sem os quais a religião torna-se irracional por não mais vivenciar, ou sequer apontar, os sinais de transcendência.

Por isso é o desencantamento do mundo, perpetrado pela ciência e pela própria religião, que se apresenta como um importante desafio para a proposta de Peter Berger. Sublinhe-se que "desencantamento em sentido técnico não significa perda para a religião nem perda de religião, como a secularização, do mesmo modo que o eventual incremento da religiosidade não implica automaticamente o conceito de reencantamento" (BERGER, 1997, 120).

A eticização perpetrada pela religião no Ocidente, particularmente pelo monoteísmo judaico-cristão, varreu qualquer pretensão salvífica da magia, e mais, tornou-a um antagonista a ser combatido, ao exigir um acréscimo racional em suas explicações para a fé, expõe-se ao campo cognitivo oposto, o do racionalismo e do secularismo. "É a consumação da relação religiosa como ética religiosa, na supremacia da ética sobre a teologia. Noutras palavras, é o triunfo da religião eticizada sobre a religião ritual-sacramental embebida de magismo" (BERGER, 1997, p. 182).

O desencantamento do mundo liga-se, portanto, "tanto em termos de atribuição causal quanto em sua própria base material-textual, ao ethos ascético intramundano das seitas protestantes" (BERGER, 1997, p. 200). 
O protestantismo ascético fez a proeza de reunir numa mesma conduta de vida racional e santificada - eis um tema weberiano por excelência - a rejeição religiosa do mundo com a intramundanidade da ação religiosamente válida. "Talvez nunca tenha existido", diz Weber, "uma forma mais intensa de valorização religiosa da ação moral do que aquela provocada pelo calvinismo em seus adeptos" (BERGER, 1997, p. 202).

\section{Considerações finais}

Ainda que a realidade mais genérica da religiosidade protestante brasileira - aqui chamada evangélica - não seja tão calvinista assim, nem tão eticizada, importa-nos considerar os direcionamentos daquele importante e socialmente marcante segmento denominado neopentecostalismo, que se volta para o cotidiano, para o aqui e agora. Ainda que não só ali, no neopentecostalismo, perceba-se tal inclinação. $\mathrm{O}$ "bem-estarismo" vai grassando em outras religiosidades que não apenas a evangélica ${ }^{4}$. Até aí nada de muito novo, Weber já havia apontado que "a ação religiosa ou magicamente motivada, em sua existência primordial, está orientada para este mundo" (WEBER, 2009, p. 279).

A peculiaridade, agora, é que os sinais de transcendência oferecidos por Peter Berger passam a ser entendidos e buscados pelos sujeitos aderentes aos novos sagrados bem-estaristas, e para os quais a religião ainda possui importante força social, nem tanto como doadores de sentido último, mas como porta de entrada de bens para a satisfação nesta realidade da condição humana. Ainda que as religiões continuem a deter importante valor simbólico (BOURDIEU, 1999), os vínculos do indivíduo com as instituições foram enfraquecidos.

Hélio Alves de Oliveira (2012, p. 2) destaca que "o ser humano contemporâneo tende para uma religião individualizante e descomprometida, o que contribui para a falta de sentido". Assim, observamos o surgimento de novos sagrados, além da repaginação dos antigos sagrados, que parecem não se importar tanto, ou tão profundamente, com a

4 Ver o trabalho de Bernardo Lewgoy (2008) em "A transnacionalização do espiritismo kardecista brasileiro". Disponível em: <https://bit.ly/2M1RDjS>. Acesso em 20/06/2014. 
questão das estruturas de plausibilidade, posto que voltados ao atendimento das satisfações dos indivíduos - não sabemos quem somos, mas sabemos o que queremos!

E para dar conta dessa demanda, as instituições eclesiásticas, ou religiosas em geral, agem mercadologicamente. Agem assim pois a enaltecida individualidade e soberania dos sujeitos os põem em liberdade de escolha; não há mais submissão, apenas a voluntariedade é possível.

Resulta daí que tradição religiosa, que antigamente podia ser imposta pela autoridade, agora tem que ser colocada no mercado. Ela tem que ser vendida para uma clientela que não está mais obrigada a comprar. A situação pluralista é, acima de tudo, uma situação de mercado e as tradições religiosas tornam-se agências de mercado e as tradições religiosas tornam-se comodidades de consumo. E, de qualquer forma, grande parte da atividade religiosa nessa situação vem a ser dominada pela lógica da economia de mercado (BERGER, 1997, p. 149).

Verifica-se que o neopentecostalismo tenha disparado um processo de remagificação. No neopentecostalismo entraram "aspectos mágicos com o instrumental herdado[...] como novenas[...], bênção da água[...], óleo, flores, chaves etc." (MENDONÇA, 2008, p. 139).

A maioria dos autores está de acordo em reconhecer nas práticas mágicas os seguintes traços: visam objetivos concretos e específicos, parciais e imediatos (em oposição aos objetivos mais abstratos, mais genéricos e mais distantes que seriam os da religião); estão inspiradas pela intenção de coerção ou de manipulação de poderes sobrenaturais (em oposição às disposições propiciatórias e contemplativas da "oração", por exemplo); e por último, encontram-se fechadas no formalismo e no ritualismo do toma lá dá cá (BOURDIEU, 1999, p. 45).

É assim que a remagificação de objetos e palavras perpetrada pelo neopentecostalismo ocorre com propósitos majoritariamente imediatistas. A esfera espiritual com seus anjos e demônios haverá de ser en- 
tendida como elemento a ser dominado para a concretização da vida no aqui e agora: sejam a saúde, o emprego, a casa, o carro novo ou os relacionamentos amorosos. O produto religioso é ofertado como saída rápida para situações desconfortáveis, normalmente as de caráter material.

As sugestões de Berger para um possível caminho para a teologia, e as críticas feitas aos empreendimentos teológicos, em última análise, são dirigidas aos intelectuais e profissionais do pensamento teológico imersos em secularidade. Entretanto, tendo-se em conta o desenrolar desse vasto e longínquo processo histórico que é o desencantamento do mundo ligado à sociedade de consumo, entendemos que o desafio para a proposta teológica de Peter Berger não se dá apenas na disputa cognitiva, no campo do embate de ideias, de cosmovisões aparentemente conflitantes, mas também no nível volitivo, posto que os indivíduos, ainda que guardem crenças no "sobrenatural", o fazem com objetivos mundanamente orientados, mais para satisfação de vontades do que de necessidades de teodiceias (sentido) que norteiem seu cotidiano.

Discutir ideias e moldar consciências não é tarefa desprezível, mas remodelar vontades profundamente enquadradas em esquemas de mercado e de espetáculo é um feito que aparenta requerer muita ajuda sobrenatural.

O quadro sociológico no qual se insere o teólogo não representa apenas o risco de adaptação ou capitulação a uma maioria cognitiva do racionalismo, mas também o risco de adaptação ou capitulação a religiosidades de mercado, nas quais prevalece o utilitarismo e o individualismo, cuja produção de bens vendáveis aos consumidores de tais religiosidades faz um estreitamento ótico que conduz qualquer perspectiva tão somente às questões imediatas, em detrimento daquela busca por sentidos últimos, em detrimento da busca por sinais de transcendência que possam dignificar e unir.

\section{Referências}

BERGER, P. Um rumor de anjos: a sociedade moderna e a redescoberta do sobrenatural 2. ed. Petrópolis: Vozes, 1997.

MENDONÇA, A. G. Protestantes, pentecostais e ecumênicos: o campo religioso e seus personagens. 2. ed. São Paulo: Universidade Metodista de São Paulo, 2008. 
OLIVEIRA, G. G.; OLIVEIRA, A. M. Modernidade, (Des)Secularização e PósSecularismo nos debates atuais da sociologia da religião. Revista de Teologia e Ciências da Religião na UNICAP, v. 1, n. 1, p. 24-45, 2012.

OLIVEIRA, H. A. Sintomas da falta de sentido da religiosidade contemporânea. Revista Davar Polissêmica, v. 3, n. 1, p. 1-17, 2012.

PIERUCCI, A. Desencantamento do mundo: todos os passos do conceito em Max Weber. 3. ed. São Paulo: Editora 34, 2013.

WEBER, M. Economia e sociedade: fundamentos da sociologia compreensiva. Volume 1. 4. ed. Brasília: Editora Universidade de Brasília, 2009. 